\title{
9 Indo-Tibetan Relations in Tibetan Polemical Discourse: Reconsidering Cultural Dynamics between Tradition and Innovation
}

Here, I have nothing at all to say which would be new, different, and exceed the scriptures.

Prajñākaramati, Bodhicaryāvatārapañjik $\bar{a}^{1}$

Claiming everything old as the ways of the gods

Seeing everything new as deceptions of demons [...]

This is the system of Tibet, the land of the Dharma.

Dge 'dun chos 'phel, Rgyal khams bskor ba'i snang tshul'

\subsection{Prologue: Indo-Tibetan Relations in Tibetan and Buddhist Studies}

In June 2011, only a few days before the XVI ${ }^{\text {th }}$ Congress of the International Association of Buddhist Studies in Taiwan, an exchange on the email-discussion list "H-Buddhism" caused some excitement in the global Buddhist Studies community: scholars were discussing the usage and implications of the phrase

1 BCAP (Skt.) 7.12f. (commenting on BCA I.1d and 2a): naiva kiṃcid apūrvam aparam āgamād atiriktam asmin vaktavyam asti mama |.

2 Dge 'dun chos 'phel (2009, 507):

rnying pa thams cad lha yi srol du grags //

gsar pa thams cad bdud kyi 'phrul du sems /|

ngo tshar phal cher than lhas nyid du bsgoms /|

chos kyi rgyal khams tri bho ța yis srol /I

For an alternative translation, see Lopez (2009, 101-102).

Note: Research for this article was conducted within the subproject "Buddhism between South Asia and Tibet - Negotiating Religious Boundaries in Doctrine and Practice" of the interdisciplinary research group "Negotiating Religion From a Transcultural Perspective" at the Cluster of Excellence "Asia and Europe in a Global Context," University of Heidelberg. I would like to thank Birgit Kellner and Jonathan Samuels for their helpful comments on the penultimate version of this article, as well as Douglas Fear for his meticulous copy-editing. 
"Indo-Tibetan" or "Indo-Tibetan Buddhism." ${ }^{3}$ In this, they were addressing not merely a label, but a question of larger significance, namely how forms of Buddhism on the plateau and their historical precursors on the subcontinent are related. This issue, and the shifting positions towards it, have been driving forces in the emergence of Tibetan and Buddhist Studies as individual, though closely connected, fields of enquiry - if not as clearly demarcated disciplines. ${ }^{4}$

At the end of the nineteenth century it was not only possible, but common to speak of Tibetan Buddhism merely as a deviant form of authentic Indian Buddhism, called "Lamaism." Most prominently, this was argued in L.A. Waddell's influential monograph of the same title, which portrayed Tibetan Buddhism as "poly-demonist superstition," which "is only thinly and imperfectly varnished over with Buddhist symbolism." 5 Tibetan Studies as a whole was often perceived as a mere "Hilfswissenschaft," pursued to provide Indological and Buddhist Studies access to source material that was lost in Indian languages. ${ }^{6}$ The latter view contributed to an image of Tibet as a repository for authentic Buddhist teachings, untouched by the turbulences of time. This notion was also effective in the subsequent phases of academic preoccupation with Tibet, which were shaped in a substantial way by a closer interaction between local and foreign scholars. Many of the more serious scholarly endeavours in the first half of the twentieth century made extensive use of the opportunities provided by the contact zone of the Eastern Himalayas, where they accessed Tibetans as subjects, as well as helpers, for their research. This close exchange continued in the second half of the century, when (some) Tibetan scholars were employed by Western universities or recreated their own scholastic institutions in (mostly Indian) exile, and thus provided a structured setting for academic co-operation. While Tibetan Studies developed into a field of interest in its own right, with a variety of specific methodological and disciplinary approaches (history, anthropology, art history, etc.), the study of Tibetan Buddhism, in particular, remained governed by the emphasis on

3 The respective messages were exchanged from June 11 to June 21, 2011, and can be accessed in the discussion logs of H-Buddhism: http://h-net.msu.edu/cgi-bin/logbrowse.pl?trx= lm\&list=h-buddhism [accessed December 15, 2014].

4 As Cabezón (1995a), as well as Freiberger (2009) have noted, the former on the basis of investigating the methodological and institutional set-up of Buddhist Studies, the latter by focusing on the rhetorical construction of a discipline, Buddhist Studies is a particularly heterogeneous field consisting of a great variety of methodological approaches. The same is also true of Tibetan Studies.

5 Waddell (1895, XI).

6 A still very useful survey of the history of Buddhist Studies that includes studies in Tibetan Buddhism is provided in De Jong (1997). 
a strong connection to the origin of the Buddhist religion in India. This was expressed succinctly in the title as well as the scope of David Snellgrove's influential survey-monograph on "Indo-Tibetan Buddhism" of 1987. As it is laid out in its preface, the study is based on specific conceptions of the relation between Indian and Tibetan Buddhism. Here, Tibetan Buddhism is described as being of "essentially Indian nature," as having "perpetuated forms of Indian Buddhism long since lost in the land where Buddhism originated.” The idea of a privileged access to Indian Buddhism via Tibet is also expressed in a passage of his earlier writing (from 1957) that is repeated in the later monograph: "The source in India has long been dead, and only the Tibetans possess the living traditions which can enliven the ancient places."7 While similar notions seem to have had an impact on many studies in doctrinal aspects of Tibetan Buddhism, it is also in this specific context that the relation between Indian and Tibetan Buddhism was problematised. ${ }^{8}$ Critics such as C.W. Huntington suggested that the emphasis on a strong bond between Indian and Tibetan Buddhism was largely shaped by a Tibetan view of this relation. The influence of Tibetan historiography on research in Indian Buddhist doctrine, as Huntington warns, "[...] is both subtle and profound, and we need to pay much closer attention to the ways in which principles and presuppositions of a peculiarly Tibetan brand of Indology have infiltrated our work." 9 This thought is also expressed in later writings, where he questions the usage of the expression "Indo-Tibetan Buddhism," since it "derives its authority largely on the basis of a tacit assumption that Tibetan scholars stand in some sort of historically privileged position vis-à-vis the Indian sources."10

While the relation between Buddhism in Tibet and in India was and continues to be of great importance for core questions in academic research, there seems to be only limited effort in enhancing our understanding of this relation. David Seyfort Ruegg, in an important contribution to this matter, saw a major problem in conceptualizing this relation along "the familiar opposition of stagnant stasis vs. dynamic change, a somewhat superficial and jejune dichotomy which has so frequently, and unproductively, been invoked in considering such

7 Snellgrove (1987, XIX).

8 Cautions about the usage of the term "Indo-Tibetan" in early writing were raised by Huntington (1995) and, in the same volume, Tillemans (1995).

9 Huntington (1995, 695).

10 Huntington (2003, 84, n. 6); here, Huntington also refers to several other scholars such as Dreyfus, Tillemans, and Cabezón, who address the connection between Tibetan and Indian Buddhism critically. 
matters." ${ }^{11}$ He agrees that identifying continuities and discontinuities is crucial, but suggests that we understand this distinction in a more interlinked and dynamic fashion, as "homoeostasis (dynamic stability) and internal, systemic disequilibrium leading to restoration/renewal/innovation." ${ }^{12}$ In this way, he develops a picture of Tibetan intellectual activity that is very closely connected to South Asia, but does also include the creativity and agency of thinkers on the plateau. Making a case for Tsong kha pa, a philosopher who was heavily criticised by contemporary intellectuals for being too innovative, he shows how individual elements of his thought can be aligned with Indian principles. In this way, his intellectual output, and, as Seyfort Ruegg seems to imply, that of any other Tibetan thinker for that matter, can be analyzed as a combination of two spheres: "the Indian - that is what is historically identifiable as having been taken over from Indian sources - and the Indic - that is, the meta-Indian that is typologically (if not historically) Indian," explained as a thinking "in line with Indian models and templates." 13

In practice, however, it will be difficult to draw this distinction. Whether individual notions of Tibetan thinkers are taken over from Indian sources in a literal sense, only slightly, or significantly altered can be subject to much discussion. The full controversial potential of this question will become obvious when we take a look at how Tibetan scholars conceive of their relations to Indian Buddhism and make use of them in constructing and defending who they are and what they do. As José Cabezón has argued, scholastic identity is in particular determined by a sense of tradition and orthodoxy, and a quest to maintain these with the rational methods acquired in the intellectual training within this tradition. ${ }^{14}$ It is therefore not surprising that tensions between tradition and innovation - the first understood as continuation and preservation of Buddhism from India, the second as any alteration to the former - became an important element in the way these identities are negotiated. In exploring these tensions, I will focus on examples from polemical literature, ${ }^{15}$ produced by Tibetan scholastics of the late nineteenth century. Investigating these discourses will not only shed

11 Seyfort Ruegg $(2004,321)$.

12 Seyfort Ruegg $(2004,321)$.

13 Seyfort Ruegg $(2004,340)$.

14 Cabezón (1994, 11-26). Further, the application of the terms "tradition" and "scholasticism" in a Tibetan Buddhist context is discussed in Dreyfus (2003, 6-13). This also provides a detailed analysis of educational structure and practice in Tibetan monastic institutions.

15 For a brief description of the genre of "polemical literature," see Lopez (1996). Vital elements of this genre as well as its historical developments are outlined in Cabezón and Dargyay (2007, 2-33). 
light on an emic view of the relation between Buddhism in India and in Tibet, and thereby help to sharpen our understanding of the divide or penetration between emic and etic perspectives, but also address productive mechanisms in the appropriation of Buddhism on the plateau.

\subsection{Nineteenth Century Tibetan Debates on an Indian Buddhist Classic}

When 'Ju Mi pham (1846-1912), a famous scholar of the Rnying ma school, completed his commentary on the ninth chapter of the Bodhi(sattva) caryāvatāra (BCA) on September $9^{\text {th }}, 1878$, he indicated in its title that this text should facilitate "an easy comprehension of the words and meaning" of this chapter. ${ }^{16}$ What the title did not disclose is another, and, for the present investigation, more important function, namely that it should provide his school with more sharply defined philosophical contours. These could be drawn in stand-alone treatises too, but very often Tibetan scholars preferred commentary as a medium, thereby aligning their ideas with a key text they had inherited (mostly) from India.

Mi pham's chosen work is ascribed to the Indian master Sāntideva, who was active at the beginning of the eight century CE. It quickly gained importance, not only in South Asia, but also in other linguistic and cultural contexts. The BCA was rendered into Tibetan as early as the beginning of the ninth century, into Chinese in the late tenth century, and into Mongolian in the early fourteenth century. Among these different settings the text was particularly successful on the plateau. It was translated into Tibetan three times altogether, and Rngog Blo ldan shes rab (1059-1109), ${ }^{17}$ a Bka' gdams pa scholar who participated in the final Tibetan translation, was also the first Tibetan scholar to write a commentary on the text. In the centuries to follow, the BCA received much attention and was read from a variety of perspectives: as an inspiring poem, a meditation manual, a liturgical text, or a philosophical treatise. ${ }^{18}$ Seen

16 The full title of Mi pham's work is Shes rab kyi le'u'i tshig don go sla bar rnam par bshad pa nor bu ke ta ka (Nor bu ke ta ka).

17 In providing the life dates of Tibetan scholars, I make use of the database of the Tibetan Buddhist Resource Center (TBRC), if not stated otherwise; cf. http://www.tbrc.org/. Relevant data was accessed on February 27, 2014.

18 This variety is not only encountered in modern receptions of the text, as Luis Gómez explained $(1999,267)$, but is also established in the variety of Tibetan literature that developed in relation to the BCA. 
as a standard text to explicate Madhyamaka philosophy, individual scholastic traditions of interpreting its content emerged. ${ }^{19}$ The Rnying ma school, to which Mi pham belonged, is notably late in joining this development. Here, an increasing interest in the BCA surfaced only in the nineteenth century. While Mi pham's teacher Rdza Dpal sprul (1808-1887) contributed to making this text important among a varied audience, ${ }^{20}$ it was left to his disciple Mi pham to give a specific interpretation of Madhyamaka thought on the basis of the BCA.

His commentary was often formulated in sharp contrast to, or even as a direct criticism of, other established readings, most importantly those from within the Dge lugs school. Unsurprisingly, members of this tradition where keen to defend their alignments with the BCA, and engaged in an extended series of debates, with polemical writings being exchanged over a period of almost thirty years. These controversies involved some of the most important scholastic centres of that time, with Brag dkar Sprul sku (1866-1928) and Dpa' ris Rab gsal (1840-1912), the two most prominent opponents of Mi pham, writing from the massive Dge lugs institutions of 'Bras spungs (Central Tibet) and Sku 'bum (A mdo), respectively, and Mi pham from different locations within the area of Sde dge, the cultural heart of Khams. ${ }^{21}$

The fact that Tibetan intellectuals engaged in such an extended debate over the interpretation of a single textual item of the Indian Buddhist tradition illustrates the general importance that knowledge from India acquired in a Tibetan context. Moreover, the polemical writings that were exchanged in this controversy provide us with a wealth of material to investigate how relations between Indian and Tibet were conceived of and used by Tibetan scholars. In these texts, such relations were addressed in two principally different, but interconnected aspects: as a certain historical narrative that provides a framework for Tibetan intellectual history as a whole, and in the form of concrete arguments that explicate how principles that are drawn from the general framework are enacted in scholastic practices. We will start with the former, which will first require a detour to historiographical sources.

19 Rdza Dpal sprul (1808-1887), a crucial initiator of interest in the BCA from members of the Rnying ma school, lists the following scholars as standard references for the respective scholastic traditions (see Dpal sprul mam thar 805.1-3): Bsod nams rtse mo (1142-1182) for the Sa skya school; Tsong kha pa (1357-1419) and Dar ma rin chen (1364-1432) for the Dge lugs tradition; and Dpa' bo Gtsug lag phreng ba (1504-1564/66) for the Bka' brgyud.

20 For details on the role of Dpal sprul in spreading the BCA in this specific historical setting, see Viehbeck (2016).

21 Details of the historical development of the debates and an overview map of the geographic extension are provided in Viehbeck (2014, 29-38). 


\subsection{Purity and Impurity in the Transmission and Promulgation of Buddhism in Tibet}

As has been pointed out several times, ${ }^{22}$ Tibetan historiographical accounts and notions of Tibetan cultural identity that are both the product and the basis of such accounts are significantly shaped by a view of Tibetans as righteous continuators of Indian Buddhism. While earlier sources are much more diverse in their outlook, historiographical writing after the fourteenth century ${ }^{23}$ increasingly consolidates a standard narrative of the past that has been repeated until the present day. ${ }^{24}$ There, introduction of Buddhism in Tibet, conceived of as two waves of dissemination - the "Earlier Propagation of the Teaching of the Buddha" (bstan pa'i snga dar) from the seventh to the ninth centuries, and the "Later Propagation of the Teaching of the Buddha" (bstan pa'i phyi dar) from the late tenth century on onward - is depicted as a highly regulated endeavour, in which members of the social elite, Tibetan rulers and ministers, and Buddhist scholars and translators, ensured the proper transmission of Buddhist texts, doctrines, and practices.

This concern for a controlled and institutionalised setting for propounding Buddhism is also expressed in a number of authoritative treatises, such as the introductory part of the famous Sgra sbyor bam po gnyis pa (late eighth century), which sets out rules for textual translation and for handling tantric texts, ${ }^{25}$ or the $B k a$ ' shog (ca. 986), an ordinance by the Western Tibetan king Ye shes 'od (late tenth-early eleventh century). ${ }^{26}$ The latter not only warns against non-Buddhist teachings emerging from Bon or Indian tìrthikas, but also perverted forms of texts,

22 For a significant recent contribution in this regard, see Schwieger (2000).

23 Earlier sources include a diverse body of literature such as the Royal Annals of Tibet, Old Tibetan Chronicle, Dba' bzhed, or Bka' chems ka khol ma. Later accounts are often phrased within the principles of the Chos 'byung genre, such as the famous works of Bu ston (1290-1364), Dpa' bo Gtsug lag phreng ba (1504-1564/66), or Tāranātha (1575-1634). For an overview of Tibetan historiographical literature, see Van der Kuijp (1996).

24 Schwieger identifies two main reasons for this process of "canonization" (2000, 949-950): firstly disputes with traditions that were then excluded from the main stream, and, secondly, a lack of new input from Indian Buddhists as Buddhism, as a living tradition, was disappearing from the subcontinent.

25 A comprehensive study of the Sgra sbyor and its different versions, emphasizing its character as a royal decree, is given in Scherrer-Schaub (2002).

26 Samten Karmay provides a translation of the ordinance in an earlier article (1980), and also of fragments of the work that have come to light more recently (2015). I would like to thank Birgit Kellner for pointing out newly found historiographic material on Purang-Guge rule, described by Pa sangs dbang 'dus (2012). 
practice, and doctrine within Buddhism. In particular, it mobilises against the practices of so-called "village tāntrikas," which are seen to be in conflict with the organised forms of Buddhist transmission within centralised institutions.

The issue of authentic transmission is also at the centre of the broader cultural orientation of Tibetans' religion. In the common remembrance of later Tibetan intellectuals the so-called "Debate of Samyé (bsam yas)" marks a clear turning point in the cultural stratification of the Buddhist tradition on the plateau. While the historical course of events is in various aspects unclear, Tibetans commonly depict this controversy as a formalised encounter between two individuals, conducted at Samyé, the very first monastic foundation in Tibet, and as such a place of considerable symbolic significance. ${ }^{27}$ In this view, Kamalaśîla (ca. 740-795) stands in for the Indian Buddhist tradition and its specific doctrines, which put forth a gradual path to awakening, stressing analytical inquiry and moral discipline. His opponent Hwa shang ${ }^{28}$ Mahāyāna represents the Chinese Ch'an tradition, propagating a quiescent approach according to which Buddhahood is attained suddenly and as an effect of the calming of all mental activities. Although the Chinese sources of this event paint a different picture, the Tibetan accounts inform us of the victory of the Indian side, as decided by the Tibetan ruler Khri srong lde btsan (742-800), who acted as a judge over the debate. As a consequence, the system of Indian Buddhism was introduced as the official religion of the Tibetan empire, and all adherents of Hwa shang were driven out of the country.

Historical developments were more complicated, and it is safe to assume that the cultural pluralism of the different forms of Buddhism Tibetans encountered at the fringes of their territory had effects on the way Buddhism was adopted on the plateau. Still, it is this historically and culturally simplified narrative that became effective in shaping the identities of many later Tibetan intellectuals, even down to the present day. The power of this narrative also informed scholastic discourses, in which the term "Hwa shang" was used to designate the archetype of an erring and defeated opponent. In this way, scholars commonly accused their opponents, despite the factual variety of views they professed, of adhering to a "Hwa shang view" (hwa shang gi lta ba), a view that was deemed to be nihilistic, as it would neglect the law of karmic

27 Bretfeld (2004) discusses the importance of this event as part of the "cultural memory" (in the sense of Jan Assmann) of later Tibetans. For a detailed discussion of the development, background, and content of this controversy from a historical perspective, see Seyfort Ruegg (1989).

28 This is also rendered into Tibetan as Ha shang or Hā shang. 
retribution. ${ }^{29}$ The idea of a possible threat through such a mistaken view is also reflected in the interpretation of the story of "Hwa shang's lost boot." It is said that the defeated Hwa shang left behind one shoe when he left the debate arena, which was seen as an omen that proponents of his view would still be present - left over - or come back to Tibet in later times. ${ }^{30}$

In its simplicity, this depiction of Tibetans' past seems to fulfil a clear function. It provides not only a positive model of identification, a strand of proper transmission and continuation of the Buddha's teaching from the origins in India to Tibet, but is also accompanied by, and demarcated against, a negative model, a corrupted lineage of transmission, associated with the figure of Hwa shang, "village tāntrikas," and other detractors.

Given the overarching importance of this narrative, it is not surprising that the opponents within the nineteenth century controversies about the correct interpretation of the BCA also made use of it. All of the scholars involved, in one way or another, appealed to the bifurcation of a proper and a corrupted transmission that this narrative entails. Attributions of this kind are commonly found in some elaboration in the introductory section of the individual works, so in a part of a text that, as a "paratextual threshold," 31 stages and frames the content that follows afterwards. In so doing, these elements distribute roles to the philosophical sparring partners, even before the actual exchange of arguments can be witnessed and the readership can determine these roles for itself.

The most extensive narrative of this kind is found in a critique by Blo bzang chos dbyings (1890-1949), ${ }^{32}$ the last among the Dge lugs scholars of Mi pham's time to raise objections against him. In the introduction to his critique Brotherly Companion, a Drop of Camphor that Eliminates the Suffering of the Heart of a Person of Little Intelligence: An Answer to the Critical Letter of 'Ju Mi pham 'jam dbyangs rnam rgyal rgya mtsho, Blo bzang chos dbyings sums up the development that led to the debates in the following way ${ }^{33}$ :

29 As José Cabezón points out, an analogous development can be observed for his opponent Kamalaśîla (Cabezón and Dargyay 2007, 21): “[. . ] just as Hwa shang becomes the paradigmatic 'other,' Kamalaśila becomes in some ways the paradigmatic defender of the faith [...].” 30 The topic of the shoe suggests a connection to the legend of Bodhidharma. In later Tibetan interpretations, however, the shoe of Hwa shang is clearly connected to notions of pollution and corruption, which are absent from the Bodhidharma legend. On the symbolism connected to Hwa shang's shoe, see Lopez (1996, 223, n. 5).

31 Here, I am borrowing from Gérard Genette's classic Paratexts: Thresholds of Interpretation (1997).

32 For his life dates, see Viehbeck $(2014,13)$.

33 The full title in Tibetan is 'Ju mi pham 'jam dbyangs rnam rgyal rgya mtsho'i rtsod yig gi lan blo dman snying gi gdung sel ga bur thig pa'i spun zla. The following alternates between 
Initiated by Nāgārjuna, the second Buddha, the Madhyamaka tradition - the philosophical system that was accepted as entailing the highest point of view - was spread by masters of the Prāsañgika and Svātantrika traditions and flourished in all parts of India. Then, gradually, it came to Tibet, where the "collections of the profound and vast Dharma [...] were translated well," due to the combined efforts of translators and rulers. Even though Buddhism was able to establish itself in the tradition of the Early Translation (sngar 'gyur), with an abundance of followers, "the strength of the interest of the disciples gradually diminished and hence the majority turned away from the correct path: some took their own view to be the highest, and pretended it was the sermon of the Buddha, others came into contact with wrong views such as [that of] Hā shang [...]. These people of wrong views and practices were refuted by Kamalaśila.” Further, Atiśa criticised those who took up the path of the Vajrayāna without basing themselves on the ordinary path of proper discipline, and he "adorned Tibet with the Bka' gdams teaching." Later, this was obstructed by "mistaken people from earlier times." ${ }^{34}$ At that stage, it was time for Tsong kha pa (1357-1419), the founding father of the Dge lugs tradition, to point out the correct path once again. He and his followers succeeded, but soon afterwards, "the black banner of the proponents of wrong [positions] was woven by the three, Go, Shag, and Stag," i.e., the famous critics from the Sa skya school, Go rams pa (1429-1489), Śākya mchog ldan (1428-1507), and Stag tshang lo tsā ba (b. 1405). However, the followers of the Dge lugs tradition did not allow these wrong views to prevail. Rje btsun Chos kyi rgyal mtshan (1469-1544/46), 'Jam dbyangs dga' ba'i blo gros (1429-1503), and Pan chen Chos rgyan (1570-1662) "cut [these wrong views] with the sharp knives of scripture and logic (lung rigs) and knocked them down." In the present days, there is again a detractor of Lord Tsong kha pa. This time, it is the "fearless" Mi pham, who composed "sarcastic refutations with regard to the positions (thugs bzhed) of Lord [Tsong kha pa's] own tradition” which clarify the original thought of Nāgārjuna. But also he is countered by Brag dkar Sprul sku, a Dge lugs scholar of Mi pham's time, who refutes him with "immaculate reasoning" (rigs pa dri ma med pa) and by quoting from the scriptures of Nāgārjuna's Indian successors, that is Buddhapālita and Candrakīrti. Mi pham, on the other hand, would "expound these scriptures in a wrong way, by [giving] crooked explanations."

As this excerpt clearly demonstrates, not only the concrete controversies in the nineteenth century, but also the entire development of Tibetan intellectual history prior to it, are seen along the lines of the master narrative of a proper and an improper transmission of Buddhism. Similar, though less extensive, accounts of this kind are also found in the writings of the other participants of the debate. Dpa' ris Rab gsal starts his first criticism by establishing Tsong kha pa together with his heirs, that is, the lineage of the Dge lugs school he founded,

close paraphrase and literal quotation of the respective passage ( $\mathrm{Ga}$ bur thig pa'i spun zla 129.20-132.2). For a better historical placement of the individual figures, dates were added. The full Tibetan text is provided in Viehbeck (2014, 51-52).

34 Tib. sngar gyi log rtog rnams; it is rather unclear whether this phrase refers in a very general sense to a diverse body of Buddhists that are seen to form some kind of continuation from people criticised earlier by Kamalaśīla and Atiśa, or whether it points to very concrete targets of Tsong kha pa's attacks. 
as an incontestable authority, predicted by "trustworthy scriptures and excellent beings." 35 This is contrasted with a line of detractors. Rab gsal as well mentions Stag tshang Shes rab rin chen, the famous first critic of Tsong kha pa, who "had a mind that is affected by the defect of Timira," 36 a disease, where apparently existing, but actually non-existent hairs disturb one's vision a typical example of someone whose perception is not to be trusted. Also Mi pham is seen to be criticising Tsong kha pa and his lineage unjustly. He is described as "short-tempered" (blo sna thung) and "having a partial view" (phyogs re'i mig (an) ${ }^{37}$; he would “criticise any text of his own or another's [tradition] without consideration and, in particular, be clueless in regard to the path of reasoning [...]." 38 While Mi pham is more defensive in his replies, he still has to ensure a firm place in the proper transmission of Buddhism. He explains the disparity between him and the thought of Tsong kha pa to be only superficial and based on the affiliation with his own Rnying ma tradition ${ }^{39}$ :

As for myself, I was born in this life at the feet of the teaching of the Earlier Translation (snga 'gyur pa), and as I received the nectar [of the teaching] from the mouths of great holders of the teaching, devotion towards holding on to it increased. Therefore, I was simply not caught by the demon of terrible destruction, that means, an evil attitude of disparaging the profound long-standing tradition of the Highest (i.e. the Buddha), but, aiming at a pure [presentation of the Buddhist teaching], I gave some explanations of the scriptural tradition, following the earlier highest [masters].

Similar to the model established in historiographical sources, later Tibetan scholars place great importance on the connections to India, and depict these as a line of (ideally) pure transmission of the original message of the Indian masters and ultimately the Buddha. In this, each individual element in the transmission serves to ensure that the original message is protected, and is vested with authority as a proponent of this very message. At the same time,

35 'Ju lan 370.4: yid ches pa'i lung dang skyes bu dam pa. Rab gsal's account is also discussed in Viehbeck $(2014,50-51)$.

36 'Ju lan 370.6: rab rib kyi skyon chags pa'i blo ldan.

37 'Ju lan 371.1.

38 'Ju lan 371.1-2: gya tshom du rang gzhan gyi gzhung gang la'ang skyon brjod cing/ khyad par rigs pa’i lam la rgyus med pas [...].

39 Brgal lan nyin snang 98.3-4: bdag ni skye ba 'dir snga 'gyur pa'i bstan zhabs su skyes shing bstan 'dzin chen po rnams kyi zhal gyi bdud rtsi nod pa las snga 'gyur gyi bstan pa dang de 'dzin la gus pa yar 'phel du gyur pa las/ dam pa'i ring lugs zab mo sun 'byin gyi blo ngan phung khrol ngan pa'i gdon gyis ma zin tsam gyi dwang ba gtso bor byas nas gzhung lugs kyi bshad pa cung zad re byas pa rnams sngon gyi dam pa dag gi rjes su brjod pa yin lal. See also Yang lan 464.6f., where this issue is addressed. A more detailed treatment of Mi pham's placement in terms of an established tradition is given in Viehbeck $(2014,55-57)$. 
any kind of change is seen as a deviation and a threat to the integrity of transmission. The distinction of preservers of the original teaching and deviators from it thus provides a positive mould for the identities of Tibetan scholars, but it could also be used to frame and exclude rivals. In this way, it becomes a regulating element, a tool for legitimation and for providing authority to individual proponents of Buddhism, which invokes closeness to the original message of Indian Buddhism as a principal authority.

Using this framework, individual scholars have to defend the legitimacy of their teachings by showing their conformity to the (Indian) original, and they can point out faults of opponents by proving that the teachings of the latter deviate from the original intent. This they can do by employing certain methods, foremost, by appealing to scriptural authority (lung) and logic or reasoning (rigs pa), as mentioned in the accounts discussed above.

While this gives us an idea of the general elements that are at work when Tibetan scholars legitimise what they are doing via a connection to Buddhist India, I will explore in the following how these elements are enacted in practices of argumentation. In doing so, I will draw widely from the material I have investigated more closely, that is, the texts that were exchanged between $\mathrm{Mi}$ pham and Dpa' ris Rab gsal. ${ }^{40}$

\subsection{Framing and Claiming Authority in Practices of Argumentation}

Differences in the interpretation of the BCA between Mi pham and Rab gsal pertain basically to four separate passages of the text. The contents discussed in relation to these are of a very variegated kind and range from rather insignificant issues, such as personal idiosyncrasies or even spelling mistakes, to fundamental differences in the scholastic formulations of Madhyamaka doctrine. For our current discussion, however, the contents are not very important, rather, we want to focus on how questions of tradition and innovation are treated within these.

In the various stages of the controversies and in respect to all issues discussed, both parties appeal to the idea of continuity or unity with the Indian tradition, and try to depict their opponent's statements as a deviation from the original message. Thus, a specific statement might be called a "private

40 Details of the available versions of these works by both authors, as well as their relations, are discussed in Viehbeck (2014: 83-97). 
teaching," ${ }^{41}$ a "creation of one's own mind, an intellectual fabrication," 42 a "new Tibetan tenet system" that is put forth "not in accordance with anybody" 43 rather than being a teaching that is in line with the established Indian tradition. ${ }^{44}$ As such, it not only "goes astray from the authoritative path, which consists of the teachings of the Buddha and the commentaries on their intention," ${ }^{45}$ since it "merely pulls [the original teaching] in harmony with one's own assumptions."46 In fact, it actually harms the true Buddhist teaching, as it "corrupts the meaning of the profound words of the Buddha" 47 and "defiles the beneficial scriptures of the ones from the Noble Land (i.e., Buddhist India) with the stains of one's own mind." 48 We also find this conservative attitude condensed into a question, like the following criticism ${ }^{49}$ :

How should one become someone who holds the lineage of the Victor, ${ }^{50}$

If one refutes [a statement] although one knows that it is said by the Victor?

While these examples claim a deviation in terms of an unspecified, personal fault, the debates also make use of the image of Hwa shang to place the opponent in a line of corrupted transmission. Here, the teaching of Hwa shang is associated with "a nihilistic view, not the teaching of the Buddha, but the

41 Ga bur chu rgyun 446.3: sger chos.

42 Rab lan 323.3: rang gi blo bzo rtog bzo.

43 'Ju lan 409.4: su dang mi bstun par bod kyi grub mtha' gsar pa.

44 This issue is commonly summarised under the Tibetan term rang bzo, which Matthew Kapstein explains in the following way (2000, 205): "Thus rang-bzo, literally "personal invention,' is almost always mentioned as a negative quality. A commentator assures his readers of the reliability and authority of his work by proclaiming it to be rang-bzo-med-pa, 'without personal invention."' On this concept, see also Seyfort Ruegg (2004, 329-335). Note that the concept of rang bzo, while frequently mentioned (as something to be avoided) in Tibetan scholastic knowledge production, is also endorsed in the same sense by Indian commentators, as shown, for our present example, in Prajñākaramati's commentary of the BCA, which stresses avoiding svāntrya - the Sanskrit equivalent of rang bzo - when commenting on the first verse of the BCA; cf. BCAP (Tib.) 1050.17, 1051.3, 1055.4, and 1055.8. In Sanskrit, the first parallel seems to have been on the first folio missing in La Vallée Poussin's edition; the latter three are found in BCAP (Skt.) 2.2, 5.13, and 5.16, respectively.

45 'Ju lan 403.1f.: gsung rab dgongs 'grel dang bcas pa'i gzhung lam las 'khyog pa.

46 Nor bu ke ta ka 42.5: rang gi zhe 'dod dang mthun par khrid pa tsam.

47 Rab lan 400.6: sangs rgyas kyi bka' zab mo'i don bslad pa.

48 Rab lan 198.3: rang blo’i dri ma 'phags yul ba'i gzhung bzang la bsgo ba.

49 Rab lan 323.5: rgyal bas gsungs par shes kyang sun 'byin nall rgyal ba'i brgyud 'dzin du yang ji ltar'gyur|l.

50 This is an epithet for the Buddha. 
teaching of Māra (i.e., a demon),", ${ }^{51}$ and a rival could be accused of having "written [his work] by gathering many scriptures [. . .] in order to accomplish the intention of Ha shang. ${ }^{52}$ Naturally, both opponents avoid being associated with Hwa shang, while, at the same time, they try to establish such a connection for the other, as shown for example in the following criticism by Rab gsal ${ }^{53}$ :

Despite [your] great hypocrisy of pretending to belittle the Hwa shang view, [...] there is no doubt that you have arrived from China, in the guise of a monk of the present age.

We even find allusions to the narrative of Hwa shang's lost boot, as in the following passage, which also may serve as an example for the rich rhetoric of the discourses, known for their frequent use of irony ${ }^{54}$ :

There is no doubt that you follow Ha shang Mahāyāna, but as you attained [his] lost boot as your lot, you are not even to blame!

In all these examples, notions of continuity and deviation become important for regulating questions of legitimacy. Only he who can claim to be part of the pure transmission of the Buddhist teachings from India can furnish his own elaborations with the authority that comes along with this transmission. Any association with an established aberration then deprives a scholar of this authority, as, for example, the trope connected to Hwa shang, but also irregularities embedded in personal idiosyncrasies. To refute such an accusation and to prove continuity or unity with the original teaching, a scholar can invoke certain methods.

\subsection{Scripture and Logic as a Means for Claiming Unity with the Indian Tradition}

As mentioned previously, Tibetan scholars commonly refer to scripture (lung/ $\bar{a}$ gama) and logic or reasoning (rigs pa/yukti) as means for attesting authority. As general methods, these were accepted in South Asia not only among

51 Rab lan 392.4: chad lta dang/ sangs rgyas kyi bstan pa min pa dang/ bdud kyis bstan pa.

52 Ga bur chu rgyun 431.3f.: ha shang gi dgongs pa rdzogs phyir [...] lung gi tshogs mang du bris pa.

53 'Ju lan 404.2f.: hwa shang gi lta bar smad khul gyi zob che na yang| [. . . khyed rgya nag nas da lta rab byung gi gzugs kyis byon pa gor ma chag go/.

54 'Ju lan 398.1: ha shang ma hã ya na'i rjes su song ba la the tshom med del lham lus pa bgo skal du thob pa'i phyir le lan bda' ba'ang med do/l. 
Buddhist, but also most non-Buddhist traditions. Their application and mutual relation, however, was subject to much discussion, especially in the Buddhist epistemological tradition. ${ }^{55}$ Rather than going into any of these theoretical aspects, we will explore how Rab gsal and Mi pham made use of these principles in their practices of argumentation.

Most importantly, the question of whether a specific statement is in agreement with the authoritative tradition is settled by referring to scriptural proof (lung/āgama), which in the present case means basically any scripture of Indian origin. This point is indeed crucial. Many of the problems that are discussed in the debates must be seen in the light of over eight hundred years of philosophical and exegetical development in Tibet. However, the Tibetan scriptures that, sometimes, concisely discuss these issues, play only an extremely limited role as references for proving a position. ${ }^{56}$ In the exchange between Mi pham and Rab gsal, there are several hundred references to Indian works used to prove their individual statements, while there are only a few instances where quotations from Tibetan texts are employed for the same purpose. When it comes to the discussion of whether Mi pham's view of emptiness is in agreement with scriptural authority, this asymmetry between Indian and Tibetan proof material is especially evident: to support his conception of emptiness, Mi pham quotes, for this single issue alone, over one hundred and sixty passages from various Indian scriptures (in their Tibetan translations). ${ }^{57}$ Towards the end of this enormous list of scriptural proof, we find five quotes from a treatise of Atiśa, a major authority in the "Later Propagation" (phyi dar), who travelled and taught widely in Tibet, but who had nevertheless been born in India. Later in the text, there is a loose reference to two Tibetan scholars, but Mi pham does not provide a single quote from any Tibetan author to support him in this vital issue.

References to Indian scriptures appear indeed as the most powerful tool to establish a close relation between Indian and Tibetan thought, but there is also

55 For a general introduction and an overview of different stances within the pramāna school, see Hayes (1984). Richard Nance (2007) provides a more specialised discussion in the context of Buddhist scholasticism, focusing on the meaning of reasoning.

56 This may be different in cases of dispute between members of the same Tibetan Buddhist school, where indeed Tibetan sources are referred to. In our example, where Mi pham stands in for the Rnying ma school and Rab gsal for the Dge lugs tradition, Indian sources are invoked as outside and higher authority.

57 In Mi pham's Rab lan, this list occupies about thirty-five pages with references organised, roughly, in the following manner: Prajñāpāramitā literature (pp. 257-259), other sūtras, mainly from the last cycle of teachings (pp. 259-280), śāstra literature in its historical order (pp. 280-287), tantras (pp. 288-291), and tantric literature in the form of dohās (pp. 291-292). 
a second method to prove or undermine legitimacy in general, and that is logic or reasoning (rigs pa/yukti). Especially in the present "times of degeneration," as the following quote explicates, both principles are important to eliminate misunderstanding and false prophets ${ }^{58}$ :

In the darkness that is gathering in the time of the evil aeon Fear excels owing to deceivers who have no faith.

[But] by the radiance of a million suns of scripture and logic [Their] confused words are shown as a heap of ashes.

While scriptural authority can be used to assess a concrete statement by comparing it with another (Indian) statement, the task of logic is to investigate the validity of a statement on its own grounds, and, especially, to point out possible contradictions and unwanted consequences that could be drawn from the statements of one's opponents. The principle of logic also comes into play in cases of an apparent contradiction between explanations of later Tibetan scholastics and the authoritative Indian scriptures they refer to.

Both adversaries claim their place in a line of pure transmission of Indian Buddhism and accept the general principle of unity with this tradition to fortify their positions. However, both of them, for various reasons, manoeuvred themselves into a situation where a particular statement of their interpretation of the BCA is in direct contradiction to the reading of Prajñākaramati, an eminent commentator of the eleventh century, whom both adversaries accept as the main Indian authority on the BCA. ${ }^{59}$ Confronted with the criticism that the respective interpretations would not be in accordance with authoritative scripture, here embodied in Prajñākaramati's Bodhicaryāvatārapañjikā, both scholars resorted to the principle of logic or reasoning (rigs pa/yukti) to call for a more detailed investigation of the scripture and a differentiation of different levels of meaning. As expressed in the following defence by Mi pham, a common strategy would be to distinguish between literal phrasing (sgra) and

58 'Ju lan 383.1f.:

bskal ngan dus kyi mun nag rub pa'i nang/l

yid ches bsal ba zob kyis 'jigs dam pall

lung rigs nyi ma 'bum phrag 'od zer gyis/l

ngag tshig 'chal ba thal ba'i phung por mtshon/l

59 These cases are connected to the interpretation of BCA IX.46 (and the larger question of the understanding of emptiness by Arhats) and BCA IX.78. For a detailed analysis of the respective discussions, see Viehbeck (2014, 125-150, 109-125). 
actual meaning (don $)^{60}$ and claim unity with the latter, while admitting a superficial deviation, as it is now explained, with regard to the former ${ }^{61}$ :

Individual texts put forth different ways of explanation, but why should one be tainted by a fault simply because one did not repeat solely the earlier [way of explanation] as long as there is no contradiction with regard to the meaning?

The same distinction is also drawn by Rab gsal, who further emphasises a relation of dependency between the two principles, in which the meaning of a specific statement needs to be established by reasoning ${ }^{62}$ :

Scriptures are the basis of investigating whether [their meaning] is literal or not, and [this] is determined by immaculate reasoning [...].

In this way, the authoritative power of scripture can be limited and made subordinate to reasoning ${ }^{63}$ :

Even to say that [something] was explained by many Indian scriptures is not substantial as a proof.

Also Mi pham, in his reply to the criticism by Rab gsal, agrees with the relation between scriptural authority and logic as he laid out ${ }^{64}$ :

It is explained that if one discovers the correct reasoning [of a text] by means of logic when one investigates the meaning of a text through logic, then one should give priority to logical reasoning. We, too, accept that and engage in investigation in such a way.

As indicated by Mi pham, this kind of argumentation is in line with theoretical discussions that commonly accept the supremacy of reasoning over scripture. Still, in practical terms, opponents are not likely to accept such attempts of theoretical balancing between the principles of scripture and reasoning readily.

60 This distinction is crucial in many other contexts that discuss Buddhist hermeneutics and plays a very important role, for example, in the setting forth of rules for translation from Indic languages to Tibetan, as expressed in the Sgra sbyor bam po gnyis $p a$, referred to earlier.

61 Rab lan 198.3f.: gzhung so sos 'chad tshul mi 'dra ba byas kyang don la 'gal ba med na snga ma kho na bskyar zlos ma byas pa tsam zhig gis skyon ci la 'go/.

62 'Ju lan 389.3f.: lung mams ni sgra ji bzhin yin min dpyod pa'i gzhi yin zhing/ dri ma med pa'i rigs pas gtan la 'beb pa [...].

63 'Ju lan 389.5: rgya gzhung mang pos bshad zer ba yang sgrub byed du mi che stel.

64 Rab lan 227.6: lung don rigs pas dpyad nas rigs pas 'thad pa yang dag pa mthong na rigs pa dbang btsan dgos par bshad pa ltar bdag cag gis kyang de ltar'dod nas dpyad pa la zhugs pa yin no/. 
With regard to the cases quoted, opponents considered their arguments successful as soon as a deviation, even if it was just one in literal phrasing, was admitted. Situations like those above, where Tibetan scholars admit an inconsistency, however superficial, between their own statements and the authoritative Indian scriptures are therefore rather rare. Nevertheless, these instances are important, as they illustrate central aspects of the nature and the development of Tibetan scholastic thought.

\subsection{Innovation within Tradition?}

First of all, there is the rather trivial, but not insignificant, observation that a Tibetan Buddhist scholar could decide to deviate from the Indian tradition, at least in its literal manifestations. While such a move entails very much the danger of being accused of deceit by a rival colleague, the scholar under attack could still appeal to the conceptual toolbox of Indian Buddhist hermeneutics to legitimise his viewpoint. There, support by scriptural authority and support by reasoning are given as two guiding principles. In practical terms, scriptural proof weighs very heavily, but reasoning can also be used to modify any specific statement. Reasoning thus employed can provide a loophole for Tibetan scholars, which allows them to engage more freely and creatively with the texts they inherited from their Indian predecessors. But the usage of reasoning to interpret these very texts and to determine their precise meaning can also be seen as a core element in their self-proclaimed duty to expound, transmit, and preserve the original message of Indian Buddhism with the tools they took over from this very tradition.

Understood in this sense, the agency and creativity of Tibetan scholars can very well be aligned with the standard narrative of Buddhist transmission, which develops a highly asymmetrical relationship between Buddhism in India and in Tibet. In this perspective, original, pure Buddhism emerges from India, and the Tibetans' role is limited to preserving this tradition and to defending it against any alteration. Therefore, conformity with the Indian tradition, proven through scriptural evidence, but also through logical proof, can be employed as a means to settle disputes among Tibetan philosophers who struggle for the supremacy of their individual traditions as true advocates of the original teaching. The mere fact that such differences developed, and the way Tibetan scholars react when confronted with the criticism of a possible deviation from the Indian tradition, however, reveals a creative aspect. Other than what the grand narrative suggests, enacting the principal authority of the Indian tradition is not merely a passive concession to the flow of 
Buddhism from India to Tibet, but requires the active engagement of Tibetan scholars. In this endeavour, they connect to and select individual teachings, which they interpret in a specific sense - and they are prepared to argue for their individual readings by quoting other authoritative scriptures or resorting to logical reasoning. The application of the two principles of scriptural authority and logical proof thus provides a space of negotiation in which Tibetan scholars find their identity as heirs of the Buddha in a twofold, yet connected way: as passive preservers and, at the same time, active enunciators of the original teaching.

\title{
9.7 Conclusion: Emic and Etic Perspectives in Working with Polemical Literature
}

As has become clear by now, the discourse of our present investigation, but also the entire genre of polemical literature that it is part of, is not necessarily concerned with an impartial representation and discussion of the philosophical other. Rather, its literary production is to be framed within a strong agenda of delineating and defending individual scholastic traditions. The following warning by Dan Martin therefore appears apt ${ }^{65}$ :

\begin{abstract}
When dealing with a polemic all the usual problematics of scholarly objectivity and impartiality rise to the surface. [...] We should hear and weigh the statements and arguments from all parties of course, while recognizing that polemic is extreme testimony often produced under a state of duress and usually put forward in order to induce a state of duress.
\end{abstract}

With their importance for the identity of Tibetan scholars, relations to India figure prominently in polemical discussion, and rival scholars will not miss an opportunity to scrutinise and question these relations. Even if their reasons for attacking in the first place are less than noble, they still might point us to interesting aspects in the philosophical system of an author, in particular to its more innovative features. They will not, however, spare us from the work of evaluating the argumentative validity of this system along with that of its

65 Martin (1997, 263). While I agree with Dan Martin's warning that personal agendas in writing polemical texts must be considered, it should also be noted that engagement in polemics as such, is, from a Tibetan scholastic point of view, not an extreme action, but rather standard knowledge production phrased along the idealised trio of exposition, disputation, and composition ('chad rtsod rtsom gsum). 
criticism, if that is at all what we are interested in. If we are fortunate enough to be able to deal with a more extended debate, with arguments being exchanged back and forth over several steps, we can even observe how Tibetan scholastics themselves engage in such a kind of intellectual sparring. Analysing polemical literature therefore not only shows how legitimacy in terms of a close connection to Indian Buddhism can be questioned, but also exposes strategies that have been developed to cope with such an accusation. ${ }^{66}$ Negotiations between the principles of scriptural authority and logical reasoning are a fundamental part of such processes and exhibit the productive power of these principles for the creation of Tibetan Buddhist thought, in allowing for a sliding along the (historically) Indian and (typologically) Indic scale, if we were to put it in Seyfort Ruegg's terms. While I also acknowledge this distinction as pointing to core forces in Tibetan Buddhist scholasticism, I hope I have been able to demonstrate how the tension that this distinction entails is eminent to emic discussions about the legitimacy of individual formulations of Tibetan Buddhist thought. This itself should not diminish the explanatory potential of this distinction when looking at Tibetan Buddhist writing from an outside perspective, but it should remind us to be careful in keeping these perspectives apart. And lastly, the stress laid on relations to India by Tibetan scholars themselves, but also the strong connections we observe from an outside perspective should not blind us to the possibility that some Tibetan scholars in some situations, against all odds, emancipated themselves from their Indian heritage and entertained thoughts that went not only beyond Indian sources, but also Indic models.

\section{References}

\section{Sanskrit Sources}

BCAP (Skt.) Louis de La Vallée Poussin, ed., Prajñākaramati’s Commentary to the Bodhicaryāvatāra of Śāntideva. Calcutta, 1901-1914.

66 For a list of other, potentially interesting features that the investigation of polemical literature can address, see Cabezón (1995b, 647-648). 


\section{Tibetan Sources}

\begin{tabular}{ll}
\hline BCAP (Tib.) & Shes rab 'byung gnas blo gros, Byang chub kyi spyod pa la 'jug \\
pa'i dka' 'grel. In Bstan 'gyur dpe bsdur ma. Beijing: Khrung go'i \\
bod rig pa'i dpe skrun khang, 1994-2008: vol. 61, \\
pp. 1049-1685 (TBRC W1PD95844).
\end{tabular}

Brgal lan nyin snang 'Ju Mi pham rnam rgyal rgya mtsho, Brgal lan nyin byed snang ba. In MPSB: vol. 14 (ca), pp. 97-189.

Dge 'dun chos 'phel 2009 Dge 'dun chos 'phel, Mkhas dbang dge 'dun chos 'phel gyi gsung 'bum. Vol. 2 (smad cha). Chengdu: Si khron mi rigs dpe skrun khang, 2009.

Dpal sprul bka' 'bum $\quad$ Rdza Dpal sprul, Dpal sprul bka' 'bum. 5 vols. Chengdu: Southwest Minorities Institute, 1996? (TBRC W5832).

Dpal sprul rnam thar Mkhan po Kun dpal, O rgyan 'jigs med chos kyi dbang po'i rnam thar dad pa'i gsos sman bdud rtsi'i bum bcud. In Dpal sprul bka' 'bum: vol. 5, pp. 775-853.

Ga bur chu rgyun Dpa' ris Blo bzang rab gsal, Shes ldan yid kyi gdung sel rigs lam ga bur chu rgyun. In RSSB: 423-470.

Ga bur thig pa'i spun zla Ldan ma Blo bzang chos dbyings, 'Ju mi pham 'jam dbyangs rnam rgyal rgya mtsho'i rtsod yig gi lan blo dman snying gi gdung sel ga bur thig pa'i spun zla. In Rtsod lan gyi rim phyogs gcig tu bsdebs pa thub bstan byi dor (Blo bzang dgongs rgyan mu tig phreng mdzes deb bco brgyad pa). Mundgod: Drepung Loseling Educational Society, 1996: 128-223.

'Ju lan Dpa' ris Blo bzang rab gsal, 'Jam dpal dbyangs kyi dgongs rgyan rigs pa'i gzi 'bar gdong lnga'i sgra dbyangs. In RSSB: 367-421.

\begin{tabular}{ll}
\hline MPSB & $\begin{array}{l}\text { 'Ju Mi pham rnam rgyal rgya mtsho, 'Jam mgon mi pham rgya } \\
\text { mtsho gi gsung 'bum. 27 vols., edited by Lama Ngodrup \& } \\
\text { Sherab Drimey. Paro, 1984-1993 (TBRC W23468). }\end{array}$ \\
\hline Nor bu ke ta ka & $\begin{array}{l}\text { 'Ju Mi pham rnam rgyal rgya mtsho, Shes rab kyi le'u'i tshig don } \\
\text { go sla bar rnam par bshad pa nor bu ke ta ka. In MPSB: vol. } 14 \\
\text { (ca), pp. 1-95. }\end{array}$ \\
\hline Pa sangs dbang 'dus 2012 & $\begin{array}{l}\text { Pa tshab Pa sangs dbang 'dus, “Gsar du thon pa'i spu rgyal bod } \\
\text { dang mnga' ris stod kyi rgyal rabs skor gyi rtsa che'i yig rnying ngo } \\
\text { sprod." In Rdo sbis Tshe ring rdo rje, ed., Deng rabs bod rig pa'i } \\
\text { skor gyi dpyad rtsom gces btus: 'Tshol zhib dang mtha' dpyod. } \\
\text { Lhasa: Bod ljongs mi dmangs dpe skrun khang, 2012: 601-632. }\end{array}$ \\
\hline
\end{tabular}


(continued)

Rablan

'Ju Mi pham rnam rgyal rgya mtsho, Gzhan gyis brtsad pa'i lan mdor bsdus pa rigs lam rab gsal de nyid snang byed. In MPSB: vol. 14 (ca), pp. 191-464.

RSSB Dpa' ris Blo bzang rab gsal, Gsung 'bum, Blo bzang rab gsal. Sku 'bum: Sku 'bum par khang, 199? (TBRC W00EGS1017359).

Yang lan 'Ju Mi pham rnam rgyal rgya mtsho, Mkhas mchog blo bzang rab gsal mdun phul rgyu rjes ma. In MPSB: vol. 14 (ca), pp. 464-473.

\section{English \& German Sources}

Bretfeld, Sven. 2004. "The 'Great Debate' of bSam yas: Construction and Deconstruction of a Tibetan Buddhist Myth.” Asiatische Studien 58.1:15-56.

Cabezón, José I. 1994. Buddhism and Language: A Study of Indo-Tibetan Scholasticism. Albany: SUNY Press.

Cabezón, José I. 1995a. "Buddhist Studies as a discipline and the role of theory." Journal of the International Association of Buddhist Studies 18.2:231-268.

Cabezón, José I. 1995b. "On the Sgra pa shes rab rin chen pa'i rtsod lan of Pan chen Blo bzang chos rgyan." Asiatische Studien 49.4:643-69.

Cabezón, José I., and Geshe Lobsang Dargyay. 2007. Freedom from Extremes: Gorampa's "Distinguishing the Views" and the Polemics of Emptiness. Boston: Wisdom Publications.

De Jong, Jan W. 1997. A Brief History of Buddhist Studies in Europe and America. Tokyo: Kosei Publ.

Dreyfus, Georges B.J. 2003. The Sound of Two Hands Clapping: The Education of a Tibetan Buddhist Monk. Berkeley et al.: University of California Press.

Freiberger, Oliver. 2009 (2007). "The disciplines of Buddhist Studies - Notes on religious commitment as boundary marker." Journal of the International Association of Buddhist Studies 30.1-2:299-318.

Genette, Gérard. 1997. Paratexts: Thresholds of Interpretation. Cambridge: Cambridge University Press.

Gómez, Luis O. 1999. "The Way of the Translators: Three Recent Translations of Śāntideva’s Bodhicaryāvatāra." Buddhist Literature 1:262-354.

Hayes, Richard P. 1984. "The Question of Doctrinalism in the Buddhist Epistemologists." Journal of the American Academy of Religion 52.4:645-670.

Huntington, C.W. 1995. "A lost text of early Indian Madhyamaka." Asiatische Studien 49: 693-767.

Huntington, C.W. 2003. “Was Candrakīti a Prāsañgika?” In The Svātantrika-Prāsañgika Distinction: What Difference Does a Difference Make?, edited by Georges B.J. Dreyfus and Sara L. McClintock, 67-91. Boston: Wisdom Publications. 
Kapstein, Matthew. 2000. The Tibetan Assimilation of Buddhism: Conversion, Contestation and Memory. Oxford: Oxford University Press.

Karmay, Samten G. 1980. “The Ordinance of Lha Bla-ma Ye-shes-'od.” In Tibetan Studies in Honour of Hugh Richardson, edited by Michael Aris and Aung San Suu Kyi, 150-162. Warminster: Aris \& Philips.

Karmay, Samten G. 2015. "A Decree of IHa Bla ma Ye shes 'od.” In Cultural Flows across the Western Himalaya, edited by Patrick McAllister, Cristina Scherrer-Schaub, and Helmut Krasser, 477-485. Wien: Verlag der Österreichischen Akademie der Wissenschaften.

Lopez, Donald S., Jr. 1996. “Polemical Literature (dGag lan).” In Tibetan Literature: Studies in Genre, edited by José I. Cabezón and Roger R. Jackson, 217-228. Ithaca/New York: Snow Lion Publications.

Lopez, Donald S., Jr. 2009. In the Forest of Faded Wisdom: 104 Poems by Gendun Chopel. Chicago: University of Chicago Press.

Martin, Dan. 1997. "Beyond Acceptance and Rejection? The Anti-Bon Polemic Included in the Thirteenth-Century Single Intention (Dgong-gcig Yig-cha) and Its Background in Tibetan Religious History.” Journal of Indian Philosophy 25:263-305.

Nance, Richard. 2007. "On what do we rely when we rely on reasoning?" Journal of Indian Philosophy 35:149-167.

Scherrer-Schaub, Cristina. 2002. "Enacting Words: A Diplomatic Analysis of the Imperial Decrees (bkas bcad) and their Application in the Sgra sbyor bam po gñis pa Tradition." Journal of the International Association of Buddhist Studies 25.1-2:263-340.

Schwieger, Peter. 2000. "Geschichte als Mythos: zur Aneignung von Vergangenheit in der tibetischen Kultur: ein kulturwissenschaftlicher Essay.” Asiatische Studien 54:945-973.

Seyfort Ruegg, David. 1989. Buddha-nature, Mind and the Problem of Gradualism in a Comparative Perspective. On the Transmission and Reception of Buddhism in India and Tibet. London: School of Oriental and African Studies.

Seyfort Ruegg, David. 2004. "The Indian and the Indic in Tibetan Cultural History, and Tsong kha pa's Achievement as a Scholar and Thinker: an Essay on the Concepts of Buddhism in Tibet and Tibetan Buddhism." Journal of Indian Philosophy 32:321-343.

Snellgrove, David L. 1987. Indo-Tibetan Buddhism: Indian Buddhists and their Tibetan Successors. London: Serindia Publications.

Tillemans, Tom J.F. 1995. “Foreword.” Asiatische Studien 49:641-642.

Van der Kuijp, Leonard W.J. 1996. "Tibetan Historiography.” In Tibetan Literature: Studies in Genre, edited by José I. Cabezon and Roger R. Jackson, 39-56. Ithaca/New York: Snow Lion Publications.

Viehbeck, Markus. 2014. Polemics in Indo-Tibetan Scholasticism: A Late $19^{\text {th }}$-Century Debate between 'Ju Mi pham and Dpa' ris Rab gsal. Vienna: Arbeitskreis für tibetische und buddhistische Studien Universität Wien.

Viehbeck, Markus. 2016. "An Indian Classic in 19th-Century Tibet and beyond: Rdza Dpal sprul and the Dissemination of the Bodhi(sattva)caryāvatāra." Revue d'Études Tibétaines 36: 5-44.

Waddell, L. Austine. 1895. The Buddhism of Tibet or Lamaism, with its Mystic Cults, Symbolism and Mythology, and in its Relation to Indian Buddhism. London: W.H. Allen \& Co. 
